\title{
Evaluation of Management Accounting Practices of MI Cement Company Limited: A Case Study
}

\author{
MD. Shahnewas Jiko \\ Adjunct faculty, Department of Business Administration, Southern University Bangladesh. 471, University Road, \\ Arefin Nagar, Baizid Bostami, Chattogram, Bangladesh
}

\begin{abstract}
In recent years, the Bangladesh cement industry is growing up comparing the other leading countries in Asia. By following this sequence, according to the report of Wikipedia which is mostly prepared based on "List of countries by cement production" in Hydraulic Cement Production- Asia \& The Pacific, Bangladesh has occupied the third position in producing cement in the sub-continent of Asia. This happens only for the efficient and proper utilization of the management accounting practices in the cement manufacturing industry. The success of the industry mostly depends on those taken decisions which are most relevant to achieve the goal of this firm, therefore, these should be strategically different from the competitive market and they will lead to dominate the market for a longer period by getting competitive advantages rather than other leading companies.Nowadays all institutions are related to utilizing management accounting systems to assist managers in making a sound decision to achieve the goals of the organization. Thus, the necessity of management accounting has risen not only in the manufacturing industry but also service industry (Chenhall and LangfieldSmith, 1998; Abdel-Kader and Luther, 2006; Paggios and Pavlatos,2008; Ahmad, 2012). For making a rational decision, management tools and techniques are used to obtain proper \& accurate information (Alleyne and Marshall, 2011). Among various rising industrial sectors in Bangladesh, the Cement industry is considered one of the greatest foreign currency earning sectors that contribute to the economic growth of Bangladesh (Md. Khalilur, Al Amin, Md. Abud, 2017). After fulfilling the demand of the local market every year, Bangladeshi leading cement company, MI Cement Limited which is one of the top cement exporters, export cement to the global countries including Europe and some other western countries. Unexpectedly, the implementation of management accounting practices in developing countries like Bangladesh remains unpleasant and studies on this field are very infrequent ( $\mathrm{Lin}$ and $\mathrm{Yu}, 2002$ ). Therefore, the study is designed to make an overview of the practices of management accounting especially on MI Cement Limited which has already taken up the significant position of cement manufacturing companies in Bangladesh.
\end{abstract}

Keywords: Management, Managers, Tools, Performance, JIT, Differential costing, Target Costing.

DOI: $10.7176 / \mathrm{EJBM} / 13-18-09$

Publication date:September $30^{\text {th }} 2021$

\section{Statement of the Problem:}

Due to the efficient practices of Management Accounting in MI Cement, it has secured the second position among 32 cement companies in producing and supplying products in Bangladesh and abroad (Bongonote). Besides, it has upgraded its production capacity from 11000 tons/day to 19280 tons in a day (globalcement.com). In the last 5 years, there is a constant growth rate seen in the cement manufacturing company. The main purpose of the research paper is to review the Management accounting policies, methods, and techniques that are applied by MI cement to maintain such a stable growth rate in developing countries like Bangladesh. It will also examine the Management accounting procedures and performance of MI cement to sort out what kind of standard Management practices suitable for them and why they are preferred over other practices. It also investigates the costing structure and policy which are required to maintain a sustainable profit margin and reduce the production cost of MI cement. It also focuses on the problems of Management accounting performance in taking effective managerial decisions for both internal and external users and suggests strong policy and recommendations overcome existing impediments.

\section{Literature Review:}

To make an overview of the study of the management accounting practices in the manufacturing company, many studies have been done in the aspect of this field in considering the tools and methods which are relevant with taking a decision and planning for the company. Some relevant literature has been discussed by following these sections.

Management Accounting is the method of recognizing, assessing, exploring, illustrating, and notifying information to achieve an organization's goals. Management accounting is a part and parcel of the management process. Management accountants are considered the most skilled strategic partners in an organization's national \& International management teams. Required information may vary from institution to institution based on the size of an organization, hence, the organization the bigger is, the greater information is needed for the manager 
(Hilton 2011). Ittner \& Larcker (2002, p.788) defined different methods in management accounting practices that are specially thought effective for manufacturing business to support the management accounting system \& institution's infrastructure. Budgeting, performance assessment, relevant information for decision-making, and some strategic methods used mostly among various methods are all included management accounting practices. An argument raised by Ittner \& Larcker (2001) that the advancement of these new methods has added great value in various practices and also changed the initial principles of management accounting to get the best one. Zimmerman (2001) stated that for the gradual development of information technology, extremely competitive atmosphere, and economic backdown, the tools of management accounting practices are surely changed. It is also notified from the literature that most of the manufacturing companies are not mostly benefitted by using absorption costing and marginal costing. For instance, according to Dugdale and Jones (2002), to make a proper decision as they do not give the best method to record costs exactly however there is a problem within these costing methods.

\subsection{Budgeting}

According to Drury et al. (1993), Budgeting is considered one of the most important mechanisms for predicting and directing duties of an institution and for distributing assets to achieve its goals and objectives. Drury et al. (1993) also stated that activity-based costing (ABC) and activity-based budgeting are examples of various types of budgeting. Horngren et al. (2009, p.170) defined Activity-based costing (ABC) as the best method for developing a costing method. $\mathrm{ABC}$ is mostly utilized to fix the price of a product or service in an organization. Williams et al. (2010, p. 779) prescribe ABC as "a method of overhead allocation that is used various overhead prices to identify indirect costs by the actions which take up those costs." The based on using resources required to produce a product or service, $\mathrm{ABC}$ is realized to be better than any other method for costing the product or service. Ayvaz \& Pehlivanli (2011, p. 150) have been defined Activity-based budgeting (ABB) as the budgeting of sources based on the demand of target functions. The use of this kind of application is because it gives importance to the process of activities rather than costs materials. The fundamental objective of this method is to gather all costs including ingredients, time setup, number of working hours, and manufacturing overhead. ABB is considered to be more extensive and proper as it provides detailed information of the costs to be desired that is the comparative advantage of ABB rather than ABC. Different types of budgets such as master budget and cash budget are prepared as a part of the budgeting process. The cash budget makes up cash receipts and cash payments and depicts the cash position of an institution at the end of the allotted period. The master budget fixes specific targets that need to be achieved and covers the tasks of sales or supply divisions and remaining divisions in the institution. In short, concluding that survey Drury et al. (1993) stated that most of the companies proposed to practice $\mathrm{ABB}$ over $\mathrm{ABC}$ costing systems.

\subsection{Performance evaluation}

Ittner \& Larcker (1998) described that, in today's business atmosphere, manufacturing companies are continuously facing challenges namely of that challenge is performance evaluation. Ittner et al (1997) further stated about systems that mostly given importance to financial elements like maximization of profits and return on capital projects. They have also discussed the preparation of the financial accounting information which is disrupted for the external reporting customs. These customs do not consider the increasing rate of capital and labor turnover. These detachments in performance lead a company to prepare the Economic Value Added (EVA) method. Chen and Dodd (1997, p.318) mentioned that "EVA is a variety between a company's net operating income after paying taxes and its cost of capital of both equity and debt". Presently EVA method is not considered the most useful tool among organizations but in the coming future, it may be recognized as a useful mechanism for the evaluation of performance. So, to stay focused on the goals and objectives of the company, the practice of a balanced scorecard is inevitable. Kaplan \& Norton (1992) proposed the balanced scorecard as a method for measuring the performance and controlling the financial and non-financial activities of the company properly. The main objective of the balanced scorecard is to collect information and give them to the management for the aim of strategic planning.

\subsection{Information for decision making}

It is a common belief that management accounting needs proper information for making decisions based on a short-term basis or long-term basis. Cost volume profit (CVP) analysis and customer profitability are considered most appropriate among various tools for making short-term decisions. Horngren et al (2009, p.87) explained cost volume profit analysis as a technique or method for analyzing probable changes in the company's profits, expenses, and prices. CVP analysis is used for determining how many units should be sold to achieve the break event target in manufacturing companies. Management accounting can also provide information to make financial decisions including payback periods, accounting rate of return, and discounted cash flow methods. 


\subsection{Cost and management accounting practice:}

Business organizers and administrators usually depend on cost and management accounting practices to get their relevant information. Besides various tools and applications are needed to practice to make an overview for the cost and management accounting across the firm and business community. Some related works of literature have been described below regarding the cost and management accounting tools:

Alleyne and Marshall (2011) noticed that manufacturing companies are using management accounting under five headings- budgeting, cost system, performance evaluation, information for effective decision making, and strategic analysis. They also observed that management accounting practices assist management to attain relevant information for fruitful decisions.

Ali Uyar (2010) studied that traditional management accounting tools are still important in the manufacturing sector. It also found that job costing is extensively practiced as a product cost method; prime cost, units produced and direct labor costs are considering to allocate overhead costs. Moreover, three management accounting practices are widely utilized making an effective budget, pursued by proper planning and control, and cost-volume-profit analysis. Yeshmin and Fowzia (2010) revealed in their publication on cost and management accounting practices in different manufacturing and service organizations that management accounting techniques such as financial statement analysis, budgetary control, CVP analysis, variance analysis, and fund flow analysis are mostly used in managerial functions and the variability in the application of management accounting techniques in managerial functions of the manufacturing industry is $73.343 \%$.

Mazumder (2007) revealed that traditional techniques such as financial statement analysis, standard costing, cash flow analysis, CVP Analysis, marginal costing, and fund flow analysis are extensively used but modern techniques of management accounting are not yet commonly accepted by public and private manufacturing enterprises, however, some multinational companies are started using some of them.

Fowzia and Nasrin (2011) revealed after surveying 70 listed manufacturing organizations in Bangladesh that five cost management tools such as quality costing, activity-based costing, traditional cost accounting, absorption costing, backflush costing are highly essential for making a profit planning decision. They also showed that three management tools like differential costing and kaizen costing and activity-based costing are contributing a lot to the overall performance of cost management tools.

Farjana and Das (2009) studied management performance by using management accounting techniques of the financial institutions in Bangladesh and they found some tools- budgetary control analysis and variance analysis to evaluate the managerial performance of the managers in financial institutions. Besides, managers were also found satisfied by applying these tools.

\section{Objective of the study:}

The main objectives of the present study are:

1. To highlight the management accounting policies, methods, techniques, and performance of MI Cement Ltd.

2. To identify the impediments of MI Cement Ltd and suggest an important policy for making up management accounting practices most effective.

\section{Scope and methodology of the study:}

The study has covered Management Accounting Practices of MI Cement Limited for five years (2016-2020). The research has been both theoretical and empirical. The Study has collected both Primary and Secondary data: The primary data has been collected from observing the organization, interviewing with officials and concerned experts, and discussing with the clients and related officials. The secondary data is collected from the annual report of MI cement for the period of 5 years (2016-2020), relevant journals and magazines, the official website of MI cement, the website of Chittagong Stock Exchange, and prior research work have been checked to make the theoretical structure of the study.

\section{Performance Assessment:}

The main purpose of every manufacturing business is to achieve its goal of being efficient, innovative, and flexible regarding financial and non-financial decisions, routine or non-routine decisions under a strong management board. An effective manufacturing operation is needed to provide various types of products and services to the customers, think about the benevolence of exiting employees, indicate a healthy and sound financial condition of the organization, and keep pace with the ever-changing situation of the environment. To understand whether the company is running on the right path, it's important to figure out the current changes and possible changing that may be happened in the future by analyzing the previous performance of the organization. Performance indicators help an organization to evaluate the current condition, implement an effective strategy based on the current situation. Effective indicators both measurable and actionable are required to pave a way for understanding what should measure, how it will be done, and what actions should be taken to develop the indicators in the coming future also. 


\section{Findings and their analysis:}

6.1. Evaluation of management accounting policies, methods, techniques, and performance of MI Cement Ltd:

Managers use the provision of accounting information in management accounting to better inform themselves before they decide matters within their organizations, which aids their management and performance of control functions. The activities relevant to the management accountants provide inclusive of forecasting and planning, performing variance analysis, reviewing and monitoring costs inherent in the business with the help of management accounting tools.

\begin{tabular}{|l|l|}
\hline General or Traditional Techniques & Special or Advanced Techniques \\
\hline I) Financial Statement Analysis & \\
ii) Fund Flow Analysis & \\
iii) Cash Flow Analysis & i) Activity-Based Costing \\
iv) Marginal Costing & ii) Target Costing \\
v) Absorption & iii) Just-in-Time (JT) \\
vi) Differential Costing & iv) Total Quality Management (TQM) \\
vii) Standard Costing & v) The Theory of Constraints(TOC) \\
viii) Opportunity Costing & vi) Value Added Engineering \\
ix) Budgetary Control & vii) Balanced Scorecards \\
x) Inter-firm Comparison & \\
xi) Cost-Volume-Profit Analysis & \\
xii) Management Reporting & \\
\hline
\end{tabular}

6.2 Analysis of Management Accounting Techniques being followed by MI Cement:

\begin{tabular}{|l|c|c|c|c|c|}
\hline \multicolumn{1}{|c|}{ Particulars } & $\mathbf{2 0 1 6}$ & $\mathbf{2 0 1 7}$ & $\mathbf{2 0 1 8}$ & $\mathbf{2 0 1 9}$ & $\mathbf{2 0 2 0}$ \\
\hline Financial Statement Analysis & & & & & \\
\hline Funds Flow Analysis & $\mathbf{Y}$ & $\mathbf{Y}$ & $\mathbf{Y}$ & $\mathbf{Y}$ & $\mathbf{Y}$ \\
\hline Cash Flow Analysis & $\mathbf{Y}$ & $\mathbf{Y}$ & $\mathbf{Y}$ & $\mathbf{Y}$ & $\mathbf{Y}$ \\
\hline Differential Costing & $\mathbf{Y}$ & $\mathbf{Y}$ & $\mathbf{Y}$ & $\mathbf{Y}$ & $\mathbf{Y}$ \\
\hline Marginal Costing & $\mathbf{Y}$ & $\mathbf{Y}$ & $\mathbf{Y}$ & $\mathbf{Y}$ & $\mathbf{Y}$ \\
\hline Standard Costing & $\mathbf{Y}$ & $\mathbf{Y}$ & $\mathbf{Y}$ & $\mathbf{Y}$ & $\mathbf{Y}$ \\
\hline Opportunity Costing & $\mathbf{N}$ & $\mathbf{Y}$ & $\mathbf{Y}$ & $\mathbf{N}$ & $\mathbf{Y}$ \\
\hline Budgetary Control & $\mathbf{Y}$ & $\mathbf{Y}$ & $\mathbf{Y}$ & $\mathbf{Y}$ & $\mathbf{Y}$ \\
\hline Cost-Volume-Profit Analysis & $\mathbf{Y}$ & $\mathbf{Y}$ & $\mathbf{Y}$ & $\mathbf{Y}$ & $\mathbf{Y}$ \\
\hline \multicolumn{1}{|c|}{ Special Techniques } & $\mathbf{N}$ & $\mathbf{N}$ & $\mathbf{Y}$ & $\mathbf{Y}$ & $\mathbf{N}$ \\
\hline Management Reporting & & & & & \\
\hline Activity-Based Costing & $\mathbf{N}$ & $\mathbf{N}$ & $\mathbf{Y}$ & $\mathbf{Y}$ & $\mathbf{Y}$ \\
\hline Target Costing & $\mathbf{Y}$ & $\mathbf{Y}$ & $\mathbf{Y}$ & $\mathbf{Y}$ & $\mathbf{Y}$ \\
\hline Just-in-Time (JIT) & $\mathbf{N}$ & $\mathbf{N}$ & $\mathbf{Y}$ & $\mathbf{N}$ & $\mathbf{N}$ \\
\hline Total Quality Management & $\mathbf{Y}$ & $\mathbf{Y}$ & $\mathbf{Y}$ & $\mathbf{Y}$ & $\mathbf{Y}$ \\
\hline Balanced Scorecards & $\mathbf{N}$ & $\mathbf{N}$ & $\mathbf{Y}$ & $\mathbf{N}$ & $\mathbf{N}$ \\
\hline
\end{tabular}

Notes: Data has been compiled by the researcher

\section{General Techniques:}

(a). Financial Statement Analysis: Financial statement analysis (or financial analysis) is required for an organization to review and analyze a company's financial statement to make a better decision. This statement includes the income statement, balance sheet, statement of cash flows, and return on equity.

The following table shows the net asset value per share, asset turnover ratio, return on equity, current ratio, and earnings per share of the selected year. 
Table -1

Price of net asset value per share, asset turnover ratio, return on equity, current ratio, and earnings per share of MI cement Ltd.

\begin{tabular}{|l|c|c|c|c|c|}
\hline \multicolumn{1}{|c|}{ Year } & $\begin{array}{c}2016 \\
\text { Taka })\end{array}$ & $\begin{array}{c}2017 \\
\text { (Taka) }\end{array}$ & $\begin{array}{c}2018 \\
(\text { Taka })\end{array}$ & $\begin{array}{c}2019 \\
(\text { Taka })\end{array}$ & $\begin{array}{c}2020 \\
(\text { Taka })\end{array}$ \\
\hline Net asset value per share (NAVPS) & 45.29 & 47.80 & 47.98 & 48.22 & 46.38 \\
\hline Current ratio & $1.28: 1$ & $1.2: 1$ & $0.08: 1$ & $0.11: 1$ & $0.16: 1$ \\
\hline Earnings per share (EPS & 5.01 & 4.45 & 2.13 & 1.69 & 0.89 \\
\hline Return on equity (ROE) & $12 \%$ & $10 \%$ & $4 \%$ & $4 \%$ & $2 \%$ \\
\hline Asset turnover ratio & 0.64 & 1.19 & 0.64 & 0.76 & 1.53 \\
\hline
\end{tabular}

Source: - annual reports of MICL for the years from 2016 to 2020 and computations have been made by the researchers.

It is seen from table-1 NAVPS were $45.29,47.80,47.98,48.22$, and 46.38 which showed a constant growth rate of per-share value in the financial market except for the year 2020 as Covid-19 spread out throughout the world, its causes down the price of share like others companies as well as. But in the case of current ratio analysis, the scenario is opposite the standard norm of ratio which is $2: 1$. The current ratio of MICL was 1.28,1.2, $0.008,0.11,0.16$ which are below the standard of the current ratio. The current ratio shows the reducing trend during the study and it indicates that MICL was unable to pay its short-term obligations. The decreasing trend is also seen in EPS and ROE which implies that reducing EPS causes the reduction of investors in the future of MICL in the same way constant fall down of ROE indicates the poor performance of the management team which generally fails to generate maximum profits against shareholders' investment. Asset turnover ratios were $0.64,1.19,0.64,0.76$, and 1.53 which describes a fluctuate performance though its standard ratio is 1 in manufacturing industries and it indicates that moderate efficiency in using its assets to generate revenue but the performance of 2017 and 2020 was satisfactory for the company.

(b). Fund Flow Analysis: The fund flow statement is used by MICL to analyze the reasons for changes in financial position or working capital of the company between two balance sheets. Moreover, it also displays the inflow and outflow of the funds of the company for a specific period. Broadly, it provides the management team to get the following two information:

a) Source of funds - From where the company's requisite funds will collect and how?

b) Application of funds - Where these funds will have been used to ensure a maximum profit?

Why?

Funds flow statement is also essential for long-time analysis. It is regarded as an important tool in the hands of management for evaluating the financial and operating performance of the company. The information which is provided by the funds flow statement like changes in financial position is not possible to get in the Balance Sheet and the Profit and Loss A/C. Fund flow statement is most importantly practiced to know the following answers:

i) To know the profits where it's gone

ii) To know the reason for the imbalance between the current liquidity position and the profitability position of the company.

iii) To sort out the reason for the concern solid despite its losses.

Besides, to know the working capital has been used properly by the management or not and the working capital is enough or shortage for the business, MICL uses it. It also helps the MICL management in taking policy decisions like payment of dividends etc.

Moreover, the Funds flow statement assists the investors relevant to the MICL to determine whether the company can manage the funds properly or not. It is also used to determine the Credit Worthiness of the company which shows the clear way to the lenders to determine whether they will lend money to the company or not. To make policy decisions, financing policies, and capital expenditure for the future, there is no alternative to using Funds flow statement analysis.

(c)._Cash Flow Analysis: Cash flow is practiced by MICL to analyze the company's current value and the situation based on the movement of cash inflow and outflow of the company. By using the cash flow technique as a tool, MICL can know the following answers:

i) To determine a project's rate of return or value.

ii) To determine the company's liquid assets are increasing or decreasing.

iii) To use as an alternative measure of business profits when it is thought that accrual accounting concepts do not represent economic realities of the company exactly.

The following table shows the net operating cash inflows per share of the selected year. 
Table -2

Net operating cash inflows per share of MICL during the period from 2016 to 2020.

\begin{tabular}{|l|c|c|c|c|c|}
\hline \multicolumn{1}{|c|}{ Year } & $\begin{array}{c}2016 \\
\text { Name }\end{array}$ & $\begin{array}{c}2017 \\
\text { (Taka) }\end{array}$ & $\begin{array}{c}2018 \\
(\text { Taka })\end{array}$ & $\begin{array}{c}2019 \\
(\text { Taka })\end{array}$ & $\begin{array}{c}2020 \\
(\text { Taka })\end{array}$ \\
\hline Net operating cash inflows per share & 10.68 & 1.37 & 1.36 & 3.57 & 3.69 \\
\hline
\end{tabular}

Source: - annual reports of MICL for the years from 2016 to 2020 and computations have been made by the researchers.

Table-2 depicts that net operating cash inflows per share were 10.68, 1.37, 1.36, 3.57, and 3.69 consecutively and it indicates a good financial condition of the company as its standard ratio is greater than 1 which considered by investors, and analysts to evaluate the sound financial condition of a company. Besides it means that MICL can cover all currents short-term liabilities, expenses and still have earnings leftover and up-trending operating cash flow seen in the table that provides a positive sign regarding the financial health of MICL.

(d). Differential Costing: To find out the best option between two alternative decisions, managers need to use differential costing. Among various possible options that are required to be examined, and an option must opt over others that are dropped. In taking managerial typical short term decisions, the management team of MICL applies differential analysis considering some aspects:

i) To set the prices of products.

ii) To accept or reject special orders.

iii) to add or eliminate products, segments, or customers

iv) To decide whether to make products in the factory or buying them from other sources.

v) To decide between processing or selling joint products.

(e). Marginal Costing: The marginal costing technique is used by MICL to do profit planning as it helps to determine profitability at a different level of production and sale. It is also useful in deciding the fixation of the selling price, export decision, and make or buy decision. Managers get benefitted from this tool in the evaluation of different departments is possible through marginal costing and avoiding arbitrary allocation of fixed cost, it provides control over variable cost. Under marginal costing, break-even analysis, $\mathrm{P} / \mathrm{V}$ ratio, and valuation of inventory done at marginal cost. Managers have to go through difficulties in controlling fixed cost at a certain or short period, literally fixed cost is uncontrollable in a short period but such like critical situation marginal costing plays a vital role to concentrate in control over variable cost rather than fixed cost. Somehow, it helps to control the cost of one side at all.

(f). Standard Costing: Standard costing is used by manufacturing companies like MICL to make an efficient estimation of the expenses of a production process. It helps the managers to estimate the future costs for the company because it is prepared after the consideration of all possibilities costs that may arise in the future. Besides, it is practiced to prepare a standard budget and evaluate the performance based on the company budget. Finding out the difference between actual costs and the standard one and searching the results of the arisen gap, standard costing is considered one of the best tools in this regard.

(g). Opportunity Costing: Opportunity cost is most important for making decisions from two alternatives, the cost of the rejected alternative is considered as the opportunity cost of choosing one. Opportunity cost help manufacturer like MICL to determine whether to produce or not. He can evaluate the benefit of going for a production activity by comparing it with the option of not producing at all and invest the same amount of money, time, and resources in another business or opportunity deciding which option gives more returns to opt for production or not. Moreover, implicit opportunity cost usually missing out on earning a salary income if he engages anywhere and it can be assessed by using opportunity costing. To get a fair idea about how much time and resources are worth for the company, it will be known with the help of opportunity costing.

(h). Budgetary Control: Budgetary control is a system of controlling costs that cover the preparation of budgets, coordinating the existing departments and distributing responsibilities, evaluating actual performance with the budgeted, and acting upon results to achieve maximum profitability. MICL uses budgetary control techniques to ensure planning for the future by setting up various budgets, operating different cost centers and departments with efficiency and economy, eliminating of company's wastes and increases its profitability, anticipating capital expenditure for the future, centralize the control system and take proper as well as correct steps to establish the standards structure for the company from the deviations after correction.

(i). Cost-Volume-Profit Analysis (CVP): Cost-Volume-Profit Analysis is popularly known as CVP is the point where the company experiences no income or no loss as in this point total revenues become equal with total costs (both fixed and variable costs). CVP is used by MICL to figure out how changes in costs and volume affect their operating expenses and net income. It also gives the company observe a strong insight into the profitability of their products or services. That's why CVP is considered an integral part of the profit planning process of the firm as it helps to determine the maximum sales volume to avoid losses, and the sales volume at which the profit goal of the firm will be achieved. The management team of MICL also uses CVP analysis to predict and evaluate the implications of its short-run decisions about fixed costs, marginal costs, sales volume, and selling price for its 
profit plan continuously.

Special Techniques:

(j). Management Reporting: Management reporting is used by the MICL management team to operate the organization properly by taking and making business decisions and guide the progressive flow of the company smoothly. It's an internal management reporting system that is followed by MICL to get surely the smaller details of managerial reports of every department from their respective managers and then respective managers will send these collected reports to their superior management team as they can take proper decision to achieve the goal of the company. if any wrong movement is found in the current reports, they will take preventive measures and find a solution after discussion in a correct way to dissolve this matter by analyzing the reports what they receive from different departments.

(k). Activity-Based Costing (ABC): $\mathrm{ABC}$ is needed for the managers of MICL to properly understand product and customer's net profitability and take more value-based and effective decisions which are relevant to the company's goal-oriented. It is also used for identifying accurately product or service costing that leads to taking pricing decisions properly. Besides understanding overheads as well as cost drivers, it allows the manager to make costly and non-value-adding activities whether they will keep or reduce them.

(I). Target Costing: Target costing is applied to generate the desired profitability setting the market price of the products as lowest possible comparing with the competitive companies by maintaining the same quality and standard of the production over a specific period in the future. It assures the management team that anticipated profitability targets for a product are easily achievable in the current market situation and also helps to improve sales prospects at the same time customer needs and wants are given special importance. Effectively managing a profitable product life cycle after the reduction of cost, improves the profitability for the product and its variants. (m). Just-in-Time (JIT): The just-in-time system is a management strategy of a large manufacturing company like MICL uses to reduce the holding inventory cost, inventory investment, and scrap costs that are usually seen in other companies. Moreover, this method is also applied to forecast future demand of inventory accurately, deliver received orders properly by classifying raw-materials orders from suppliers with their production schedule and increase the efficiency of materials, labor, and time of the production department. To absorb the large demand of the market in the competitive market, JIT is surely used to supply the products on time according to the demand of the clients.

(n). Total Quality Management (TQM): TQM is used by MICL as it is a continuous process of finding and eliminating errors of the employees to improve their ability and prove themselves as well trained in doing and serving effectively for the organization which is responsible for satisfying the demands and needs of the customers. TQM ensures the best products possible for the customers with the efforts and helps of the management team of MICL along with it shows the efficiency and expertise of the team management.

(o). Balanced Scorecards: Balanced Scorecards is useful for the managers of MICL to visualize the map of operational activities or operation both internal and external and check whether the operations or activities are going on according to the plan or not, however, if anything is found unexpectedly wrong, managers take preventive measures to sort out the problem immediately as they can all together achieve their company's goal properly after analyzing and measuring past performance data along with organizations feedback which is also helpful for making better decisions in the future.

6.3. Analysis of Management Accounting Practices in decision making by MI Cement Limited:

Generally, management takes both routine and non-routine decisions by using management accounting tools. Those are individually mentioned below:

\subsubsection{Routine decision making:}

Table 3: Routine decision making

\begin{tabular}{|l|c|c|c|c|c|}
\hline \multirow{2}{*}{ Techniques } & \multicolumn{5}{|c|}{ Routine Decision } \\
\cline { 2 - 6 } & Purchase & Pricing & $\begin{array}{c}\text { Acceptance of } \\
\text { Special Order }\end{array}$ & Replacement & $\begin{array}{c}\text { Continue or drop } \\
\text { Production }\end{array}$ \\
\hline BEP Analysis & & $\sqrt{ }$ & $\sqrt{ }$ & $\sqrt{ }$ \\
\hline Target Costing & & & $\sqrt{ }$ & $\sqrt{ }$ & $\sqrt{ }$ \\
\hline Just-in-Time (JIT) & & & $\sqrt{ }$ & $\sqrt{ }$ \\
\hline Differential Costing & $\sqrt{ }$ & $\sqrt{ }$ & & & \\
\hline Relevant Costing & $\sqrt{ }$ & & & & \\
\hline
\end{tabular}

Source: - annual reports of MICL for the years from 2016 to 2020 and computations have been made by the researchers.

(a). BEP Analysis: BEP analysis helps the management of MICL in the case of taking a routine decision which aims to determine the minimum output that must be exceeded for a business to secure profit along with it plays a vital role as a rough indicator in determining a project or special order whether it will be profitable or not at the 
same time the earnings impact of marketing activity including the effect of changes in sales price as well as cost and efficiency changes on profitability. To decide whether current production will continue or drop, managers also use this technique in this regard.

(b). Target Costing: The management team of MICL tries their best to provide good quality products at a standard price comparing to their competitors. To make it possible, they need to use the target costing method to utilize proactive planning, cost reduction, and cost management where they ensure initial development of product life cycle after the calculation and planning of costs properly rather than developing and designing products in the later stage of the product life cycle. Besides, customers always desire to have a good quality of products with a moderate price which is determined in the competitive market the based on needs and wants of customers who will then decide how much they willingly want to pay or spend for their desired products after considering different market segments and cost of exiting products. In that situation, the expected price and actual price of the product are fixed by the management of the company by using the target costing method.

(c). Just-in-Time (JIT): The just-In-Time or JIT is followed in the case of making inventory management decisions by the management team of MICL as it contributes to continue smoother production flow, and it is considered a key feature of the JIT system. It reduces wastage and waiting time, improves efficiency and productivity of workers and management levels, improves the relationship between suppliers and producers, and decreases various costs including inventory costs, financial costs, and labor costs.

(d). Differential Costing: The concept of differential costing is applied by the management team of MICL when multiple options are needed to evaluate like setting the prices of products, accepting or rejecting special orders, adding or eliminating products, and also deciding whether to make products in the factory or buying them from other sources.

(e). Relevant Costing: The relevant costing concept helps the managers of MICL in the decision-making process by eliminating irrelevant information about the costs that hinder making a proper decision and, managers can easily focus on existing informations from extraneous information for making the right decision.

\subsubsection{Non-routine decision making:}

Table 4: Non-routine decision making

\begin{tabular}{|l|c|c|c|c|}
\hline \multirow{2}{*}{ Techniques } & \multicolumn{3}{|c|}{ Non-routine Decision } \\
\cline { 2 - 5 } & $\begin{array}{c}\text { BMRE } \\
\text { (Balancing Modernization } \\
\text { Replacement and Expansion) }\end{array}$ & Project & $\begin{array}{c}\text { Purchase } \\
\text { Equipment on } \\
\text { Lease }\end{array}$ & $\begin{array}{c}\text { Purchase Equipment } \\
\text { on Hire Purchase } \\
\text { Budgeting }\end{array}$ \\
\hline ARR & $\sqrt{ }$ & $\sqrt{ }$ & $\sqrt{ }$ \\
\hline PBP & $\sqrt{ }$ & $\sqrt{ }$ & $\sqrt{ }$ & $\sqrt{ }$ \\
\hline NPV & & & $\sqrt{ }$ & $\sqrt{ }$ \\
\hline ROI & $\sqrt{ }$ & $\sqrt{ }$ & & \\
\hline B/C Ratio & & $\sqrt{ }$ & & \\
\hline IRR & & & & \\
\hline
\end{tabular}

Source: - annual reports of MICL for the years from 2016 to 2020 and computations have been made by the researchers.

(a). Capital Budgeting: Capital budgeting or investment appraisal is used by MICL to appraise a project's cash inflows and outflows that would be generated from long term investment like machinery, replacement of machinery, new plants, new products and meet the expectation of the company for a specific period, and it will be estimated by the management team after the evaluation of long term assets or investments based on how much returns will generate from the assets. After considering the pros and cons of a prospective project, the management team will decide whether they will accept the long-term project or investment that will be profitable for the future or not.

(b) Accounting rate of return (ARR): The accounting rate of return or the average rate of return (ARR) is a financial ratio that is highly used in capital budgeting to evaluate the return that generates from the net income of the proposed capital investment. A project will be accepted when the ARR rate is higher than the expected rate. The higher the ARR, the project will be considered more attractive as a profitable investment of the company.

(c). Payback period (PBP): For a long-term project or investment, PBP is regarded as an important determinant to know the exact length of required time when the total cost of an investment will be recovered. It also helps the management team of MICL to undertake a project or investment considering the length of time along with its returns, and then managers can decide whether the project will be accepted or rejected after analyzing the difference between the estimated time value of money and actual value of money.

(d). Net Present Value (NPV): To evaluate a project properly, time value is needed to be calculated properly as management can value future cash flows of money converting into the present value of the return. It allows 
stockholders of the company to estimate how much will be gained from the project. How much value or money a project will create for the company is known by the uses of NPV.

(e). Return on investment (ROI): The purpose of using the return on investment (ROI) metric is to measure the rate of return on invested money of a project for a specific period deciding whether the project will be accepted or not. Besides, it is also essential as an indicator to determine comparing various projects or investments based on the highest ROI which is specially prioritized for investment.

(f). Benefit-cost ratio (BCR): The benefit-cost ratio (BCR) is used to evaluate the overall value for money which is expressed in qualitative items or monetary of a proposed project showing the relationship between costs and benefits related to the project. It is also useful for analyzing the risk involved with the proposed project and creating an opportunity for the managers to have a look at the overall feasibility of the project as well as current affordability.

(g). Internal rate of return (IRR): The internal rate of return (IRR) method is important for the management team of MICL to consider the time value of money when managers evaluate a project for the future. It also helps the manager to visualize the overall situation of the project. After evaluation of the project when they find that the IRR rate is higher than the cost of capital or IRR is greater than their estimated rate of return, only then they can make a proper decision either accept the project or skip the project.

\subsubsection{Practices of MA in Controlling Decision:}

Table 5: Practices of MA in Controlling Decision

\begin{tabular}{|l|c|c|c|c|}
\hline \multicolumn{1}{|c|}{ Techniques } & $\begin{array}{c}\text { Cost } \\
\text { Control }\end{array}$ & $\begin{array}{c}\text { Performance } \\
\text { Measure }\end{array}$ & $\begin{array}{c}\text { Target } \\
\text { Achievement }\end{array}$ & $\begin{array}{c}\text { Refund } \\
\text { option }\end{array}$ \\
\hline Standard Costing & $\sqrt{ }$ & & & \\
\hline Flexible Budget & $\sqrt{ }$ & $\sqrt{ }$ & \\
\hline Responsible Accounting & $\sqrt{ }$ & & $\sqrt{ }$ & $\sqrt{ }$ \\
\hline Budgetary Control & $\sqrt{ }$ & & & $\sqrt{ }$ \\
\hline Management Reporting & & $\sqrt{ }$ & \\
\hline Activity-Based Costing & & $\sqrt{ }$ & \\
\hline Opportunity Costing & & $\sqrt{ }$ & $\sqrt{ }$ \\
\hline Marginal Costing Statement & & $\sqrt{ }$ & $\sqrt{ }$ & \\
\hline Cash Flow Analysis & & $\sqrt{ }$ & & \\
\hline $\begin{array}{l}\text { Financial } \\
\text { Analysis }\end{array}$ & & & & \\
\hline
\end{tabular}

Source: - annual reports of MICL for the years from 2016 to 2020 and computations have been made by the researchers.

(a). Standard Costing: Maximum profit is ensured by the management team of MICL by controlling costeffectively which is done by finding the difference between the actual cost and standard cost that is desired by the company. In that situation, standard costing helps the managers to find out the best costing price that ensures the maximum profit of MICL. In taking a costing-related decision if needs to take corrective actions while planning about costs, it is also helpful in this regard to sort out the actual gap between standard cost and actual cost.

(b) Flexible Budget: The Flexible budget lets the managers of MICL know about the total financial condition of the company along with its different levels of expenses like variable costs that are changing when actual revenue changes. It is also necessary for the company taking instant corrective decisions with changing the financial condition and tracing those unexpected costs that are required to achieve the company's larger financial goal.

(c) Responsible Accounting: To account for the company's internal planning, budgeting, and performance of the management levels of all separate departments, Responsible accounting is applied by the top-level management of MICL. It provides relevant information to the management of individual department's monthly and annual budgets to evaluate their performance that indicts the efficiency of individual employees and based on their performance, management decides whether they will be rewarded or not. It is also used to know the difference between pre-planned targets and actual results, from the difference then management can decide their taken decision will achieve the expected output or not.

(d). Budgetary Control: Budgetary control is a useful mechanism for controlling the expenditures of the MICL along with maintaining a proper balance between the income and expenditure for a certain period. It is also useful for estimating the future expenditures and revenues of the organization by using forecasting techniques. After getting estimated data and their findings, managers compare profit and expense between normal conditions and the estimated rate of return. Finding out the variance, management tries to fix it and make correct decisions to achieve the company's desired goal. Besides, it ensures proper utilization of the resources of MICL by reducing the expenditures of different departments.

(e). Management Reporting: To run the organization effectively, managers need to collect all relevant 
information that is helped by the management reporting system. Managers from different departments send their individual department's data to the management team for evaluating their performance. From these reports, management will collect important data that is used to improve decision-making, marketing plans, future forecasts, and budget planning. They also utilize information to trace growth and development, find out the impediments that may require further evaluation for the fulfillment of the company's goal.

(f). Activity-Based Costing: Activity-based costing is very effective in measuring the performance of the organization and taking pricing decisions accurately. It is popularly used by the managers of MICL to understand various types of overhead costs, reduce costly and non-value added products and take strategic decisions like outsourcing, identification, and evaluation of process development activities.

(g). Opportunity Costing: Finding the best decision among various alternative decisions, opportunity cost helps the managers to take such important decisions after analyzing the pros and cons of different projects including its costs with best returns. The company wants to secure its profit by reducing costs which generally estimates by them and wants to achieve this target by applying the opportunity costing method.

(h). Marginal Costing: The marginal Costing technique is very effective as a decision-making technique. It helps the manager of MICL to decide whether they will produce a product or buy it from other sources and what will be fruitful for the company, all these answered will be gained by using this technique. It is also useful for the company to do profit planning, set pricing of products, and in taking make or buy decisions also.

(i). Cash Flow Analysis: Cash flow analysis helps the managers to decide the proper utilization of the company's liquidity that is generated from cash inflow and outflow of the company whether the company's liquid assets are increasing or decreasing and also provided cash information is used as inputs in financial models, rate of return and net present value, to determine if the projects will be fruitful or not.

(j). Financial Statement Analysis: Financial statement analysis is required for not only knowing the financial health condition of MICL but also making a correct decision to lead the operational activities on the proper track. It also helps both managers and outside investors to know the financial condition and make effective decisions from the recorded data which are received from different departments after the evaluation of income statement, balance sheet, statement of cash flows, and statement of changes in equity.

7. Identification of Impediments to the Management Accounting Practices: From previous research works and talked with professional's body, the given impediments below are currently faced by MICL.

\begin{tabular}{|l|l|}
\hline SN & \multicolumn{1}{|c|}{ Problems } \\
\hline (a). & Lack of Management Accounting Professionals \\
\hline (b). & Poor Implementation of Cost Measurement Plan and Techniques \\
\hline (c). & Costly Process \\
\hline (d). & Forecasting only Current Economic Situation \\
\hline (e). & Poor Cost Control \\
\hline (f). & Ineffective Cost Audit \\
\hline (g). & Poor Financial Planning \\
\hline (h). & Time-Consuming to take Management Decisions \\
\hline (i). & Lack of separate department for Management Accounting \\
\hline
\end{tabular}

(a). Lack of Management Accounting Professionals: Professionals are recruited for taking proper decisions for the betterment of MICL by analyzing collected data which are developed by using numerous management tools. But they failed to show their skills in this regard when we notice the results getting from financial statement analysis. Here, the current ratio couldn't meet the required demand that indicates MICL is unable to pay its short time liabilities. Besides, EPS and return on equity rate were also seen a downward trend which indicates the reduction of investors for the future, and professionals are failure to generate maximum profit for the company against investors investment.

(b). Poor Implementation of Cost Measurement Plan and techniques: MICL has own cost structure plan for measuring the components of cost but sometimes due to the rush trend of managers and complexity of using tools to make costing decision, they don't apply cost measurement plan properly. That's the reason for increasing per head manufacturing production cost.

(c). Costly Process: Sometimes top-level management needs to hire an experienced person for any special purpose or project to evaluate the pros and cons of the project and to develop and operate the company's management accounting process. For these reasons, the company has to pay additional salaries to the professionals.

(d). Forecasting only Current Economic Situation: Management accounting system applies sales or production models that only account for the current economic condition of the company rather than future economic condition. That's why owners and investors keenly ensure their future return as the management team fails to make the correct decision and predict the future condition of the company. 
(e). Poor Cost Control: Poor Cost Control is strongly noticed in the income statement while considering net asset value per share though it should be constant in the middle of the period slightly downward trend was also seen there. This indicates that MICL was a total failure in reducing their extra costs.

(f). Ineffective Cost Audit: MICL doesn't keep any permanent cost auditor who will check this sector after a regular interval and give suggestions if any changes are noticed in the costing sector that is required to control the cost-effectively.

(g). Poor Financial Planning: The company's mission, objectives, budgeting, costing, and allocation of resources are all the components of financial planning but poor cost measurement, budgeting, and poor feedbacks from assets indicating the poor financial planning of the company.

(h). Time-consuming to take Management Decisions: Management accounting techniques are used for making the right decisions timely but it's a lengthy and time-consuming process while measuring the costing sector of the company. For this reason, management fails to make costing budget and decisions properly that hampers the company's growth.

(i). Lack of separate department for Management Accounting:

MICL has only a single department for the accounting and finance section where there is no special department for controlling and measuring manufacturing cost, R\&D, and management decisions.

\section{Important policy implications for making up management accounting practices most effective:} Some important policies are recommended for overcoming current problems which are found from the study.

(a). Recruit skilled Management Accounting Professionals: Current Accounting professionals failed to prove their proper skills in analyzing data and making the right decision for the betterment of the company. In this situation, the company should recruit skilled professionals to lead the company in a better place than the existing manufacturing company in Bangladesh.

(b). Effective Implementation of Cost Measurement and techniques: To ensure the implications of the company's cost measurement plan, managers need to use costing techniques properly and they should learn how to use these techniques in a hard situation also. Because of the continuous use of these techniques, they will get acquainted with tools. Moreover, they become user-friendly while using in any complex situation. Then they can take proper decisions to reduce per head manufacturing costs that will ensure maximum profit gaining.

(c). Reducing Cost to Determination Process: Recruitment of specialists for any special project or purpose is one kind of extra cost for the company. But according to the previously suggested policy, if a company recruits skilled professions, they will handle all projects smoothly and properly. In this way, the company can reduce its relevant cost regarding the cost determination process.

(d). Forecasting both Current and Future Financial Situation: Management should take into account both current and future financial situations as they can get a proper idea about the current financial condition and decide what they have to do in the future considering and analyzing the present condition while applying financial models such as production and sales. Investors and owners can have a clear idea about the rate of return on their invested amount

(e). Improve Cost Control Policy: As the existing cost control policy couldn't bring positive output for the company, the company should apply some new policies for controlling the cost in such a way that they can easily differentiate between standard costing and actual costing. Then they can take preventive measures to cope with standard costing if any negative variance is seen in the current plan. Management should apply cost controlling techniques such as marginal costing, standard costing, direct costing, and absorption coting properly to estimate cost accurately in taking decisions.

(f). Improve Cost Audit: Auditing is essential to check every financial movement of the company for securing maximum returns by deducting unnecessary costs that are achieved through standard cost auditing. So, MICL needs to improve this sector by increasing its rates of return from investment.

(g). Improve Financial Planning: To achieve the company's fixed objectives, MICL needs to focus on smart budgeting relevant to the goals, reducing costs, and allocation of assets such that they can get maximum returns from the assets.

(h). Reducing Time-Consuming to take Management Decisions: Practicing management accounting is a lengthy process as after getting the results only then they can make a decision. That's why taking prompt decisions can't be possible by inexperienced managers while expert and skilled managers can easily understand after seeing data or information. So, MICL needs to develop this sector as they can get the proper decision within the required time as possible.

(i). Make separate department for Management Accounting: MICL should make every individual department for management accounting as each department can make their report and decision. This process will ensure the highest performance of the managers because they won't find any space to blame others while any wrong movement is seen in any sector. Then, whole blame will put on them and it won't hamper the progress of other departments. 
9. Conclusion: The current study on MICL has been evaluated critically the management accounting practices during the period 2016-2020. The study found that what management techniques and methods are applied by MICL to lead the manufacturing sector in Bangladesh. In the case of performance evaluation, MICL is currently unable to meet short-term obligations and the management team is a failure in making maximum profit. Besides, poor allocation of resources is also found in this study. Except for these mentioned problems, the overall performance of MICL is found satisfactory. The study also found the current problems of MICL and suggested policies to overcome these problems also. Finally, these discussions lead us to summarize that further study might be considered to analyze the performance of MICL and the current study will play the role as a guideline in this perspective.

\section{References:}

1.https://en.wikipedia.org/wiki/List_of_countries_by_cement_production.(Wikipedia, 28 February 2017, at 13:17 (UTC)).

2. Chenhall, R. H. \& K. Langfield-Smith (1998) "Adoption and Benefits of Management Accounting Practices: An Australian Study", Management Accounting Research 9(1), 1-19.

3. Alleyne, P. \& D. W. Marshall (2011), "An Exploratory Study of Management Accounting Practices in Manufacturing Companies in Barbados", International Journal of Business and Social Science 2(9), 49-58.

4. Ronald W. Hilton, D. E. (2011). Managerial Accounting: Creating Value in a Global Business Environment. McGraw-Hill Higher Education.

5. https://bangladeshbusinessdir.com/cement-companies-in-bangladesh/ (List of top cement manufacturer companies in Bangladesh).

6. Lin, Z. J., \& Z. Yu (2002), "Responsibility Cost Control System in China: The Han Dan Experience", Asia Pacific Business Review 9(1), 59-78.

7. Md. Khalilur Rahman, Al Amin Talukder, Dr. Md. AbudDarda "Extent of Use of Cost and Management Accounting in the Cement Industry of Bangladesh", European Journal of Business and Management, Vol.9, No.36, 2017.

8. Zimmerman, J. (2001), “Conjectures Regarding Empirical Managerial Research”, Journal of Accounting and Economics 32(1-3), 411-427.

9. Ittner, C., \& Larcker, D. (2002). Empirical managerial accounting research: Are we just describing management accounting practice? European Accounting Review, 11(4): 787-794.

10. Ittner, C., \& Larcker, D. (2001). Assessing empirical search in managerial accounting: a value-based management perspective. Journal of Accounting and Economics, 32: 349-410.

11. Dugdale, D., \& Jones, T. C. (2002). Battles in the costing war: UK debates, 1950-1975. Accounting, Business, and Financial History, 13(3): 305-338.

12. Drury, C., Braund, S., Osbourne, P., \& Tayles, M. (1993). A Survey of Management Accounting Practices in the UK Manufacturing Companies, The Chartered Association of Certified Accountants, London, Chapter 6, pp. 41-48.

13. Horngren, C.T. Datar, S. Foster, G.Rajan, M., \&. Ittner, C. (2009). Cost Accounting: A Managerial Emphasis. 13th edition, New Jersey, Upper Saddle River: Prentice-Hall.

14. Williams, J., Haka, S., Bettner, M., \& Carcello, J. (2010). Financial \& managerial accounting: The basis for business decisions (15th ed). Boston: McGraw-H.

15. Ayvaz, E., \& Pehlivanli, D. (2011). The use of time-driven activity-based costing and analytic hierarchy process method in the balanced scorecard implementation. International Journal of Business and Management, 6(3): 146-158.

16. Ittner, C., \& Larcker, D. (1998). Innovations in performance measurement: trends and research implications. Journal of Management Accounting Research, 10: 205-238.

17. Ittner, C., Larcker, D., \& Rajan, M. (1997). The choice of performance measures in annual bonus contracts. The Accounting Review, 72(2): 231-255.

18. Chen, S., \& Dodd, L. (1997). Economic value added (EVA(TM)): An empirical examination of a new corporate performance measure. Journal of Managerial Issues, 9(3): 318-333.

19. Kaplan, R., \& Norton, D. (1992). The balanced scorecard measures that drive performance. Harvard Business Review, January/February, 71-79.

20. Top 10 Cement Companies In Bangladesh 2021 - Bongonote.

21. https://www.globalcement.com/news/itemlist/tag/Bangladeshs

22. Alleyne, P. \& D. W. Marshall (2011), "An Exploratory Study of Management Accounting Practices in Manufacturing Companies in Barbados", International Journal of Business and Social Science 2(9), 49-58.

23. Uyar, A. (2010), "Cost and Management Accounting Practices: A Survey of Manufacturing Companies", Eurasian Journal of Business and Economics 3(6), 113-125.

24. Yeshmin, F. and R. Fowzia (2010), "Management Accounting Practices: A Comparative Analysis of 
Manufacturing and Service Industries", ASA University Review 4(1), 131-141.

25. Mazumder, B. C. (2007), "Application of Management Accounting Techniques in Decision Making in the Manufacturing Business Firms in Bangladesh", The Cost and Management 35(1), 5-18.

26. Fowzia, R. \& M. Nasrin (2011), "Appraisal of Cost Management Tools in Manufacturing Organizations of Bangladesh", World Journal of Social Sciences 1(2), 83 - 94.

27. Farjana, Y. \& S. Das (2009), "Management Accounting Techniques: Appraisal of Managerial Performance of the Financial Institutions in Bangladesh", A Corporate Professional Journal of the Chartered Secretary 11(3), 25-32. 